\title{
Total Factor Productivity Growth of African Public Universities
}

\author{
Ngobi Kiwanuka Robert ${ }^{*} \quad$ Yawe Bruno Lule ${ }^{2}$ Ddumba-Ssentamu John ${ }^{2}$ \\ 1.P.O. Box 24911 Kampala, Uganda (Permanent Address) \\ 2.School of Economics, Makerere University, P.O.Box 7067 Kampala, Uganda
}

\begin{abstract}
The study investigates the Total Factor Productivity Growth of 15 African public universities using the DEABased Malmquist Productivity Index. The general model, teaching-only model and research-only model are estimated. The operating environment is adjusted to ascertain the extent to which it affects the productivity of the African public universities. Total factor productivity gains for African public universities averaged at $7.5 \%$, $0.7 \%$ and $6.8 \%$ for the general model, teaching-only model and research-only model, respectively. Productivity improvements are therefore majorly a result of research productivity gains rather than teaching productivity gains before and after adjusting for the operating environment. The university research productivity gains are, however, mainly attributed to technological progress rather than technical efficiency change.
\end{abstract}

Keywords: African public universities, Malmquist Productivity Index, Technical efficiency change, Technological change, Total factor productivity growth

DOI: $10.7176 / \mathrm{JESD} / 10-2-16$

\section{Introduction}

Universities in Africa are majorly a post-colonial phenomenon with the exception of North Africa and South Africa (Sawyerr, 2004). The Post-Colonial African universities were explicitly a public undertaking during the 1960s and 1970s (Johnstone, 2006). The economic pickles of the 1980s climaxed into the Structural Adjustment Programs (SAPs) that resulted in an ideological shift in educational funding towards primary \& secondary levels (Obong, 2004). The ideological shift in educational funding away from higher education amplified a severe crisis. The crisis manifests itself among others through: high graduate unemployment rates, exploding student enrolments, inadequate infrastructure, unregulated photocopying flouting copyright laws, duplication of programs, low internet connectivity, poor staff remunerations and moonlighting by the faculty (Mutala, 2009).

The continuous decline in state funding in real terms to African public has incapacitated their seamless provision of quality teaching and research services. Worse still, African public universities have limitations in their pursuit to generate additional financial resources. They are not at liberty to freely adjust tuition fees upwards, have low alumni giving \& endowment funds while public private partnerships \& consultancies as sources of additional funding are underdeveloped (Cunha \& Rocha, 2012). African public universities, however, have more academic programs and staff across qualifications \& ranks than their private counterparts. There is hence an ever-growing interest to establish the productivity of African public universities. The sources and the nature of total factor productivity growth of African public universities are, however, not well known.

The objective of the study is to investigate the total factor productivity growth of 15 African public universities using the 2000-2007 data set. The "general model", "teaching-only "model and "research-only" model are estimated. The Knowledge-Transfer-Only Model is not analysed but preliminary investigations did not show significant differences based on discipline distinctions. The universities under investigation are listed in Table 4. The universities are flagship ${ }^{1}$ universities in their respective countries and South Africa based universities were selected based on their comparability in terms of size to the flagship universities selected outside South Africa. The University of Cape Town is selected as a pace setter because it has been ranked as the best university in Africa over time. The analysis of the total factor productivity growth is important in determining the extent to which technical efficiency (catching up) and technical/technological progress affect the teaching and research productivity of African public universities. Cross-universities and cross-country comparisons further facilitate cross-fertilization of the best practices in the teaching and research functions of universities.

\section{Theoretical Framework}

Productivity growth is usually a result of three sources: growth in inputs to production, improvement in efficiency of the production processes and technological change. The residual growth in real output not attributed to the growth in inputs is the total factor productivity growth (Nishimizu \& Page, 1982). Total factor productivity growth is decomposed into: changes resultant from a movement towards the best practice frontier (technical efficiency change) and shifts in the best practice frontier (technological/technical change)

\footnotetext{
${ }^{1}$ Flagship universities have three attributes: (i) they are the cornerstones of the public higher education systems, (ii) often the first public universities to be established and (iii) are the most prominent centers for research and graduate training in their respective countries or cities (Bunting \& Cloete, 2012; Berdahl, 1998).
} 
(Ramanathan, 2003). Following Coelli et al (2005), Figure 1 is applied to analyze the productivity change of decision making units producing $\mathrm{Y}$ output using inputs $\mathrm{X}$.

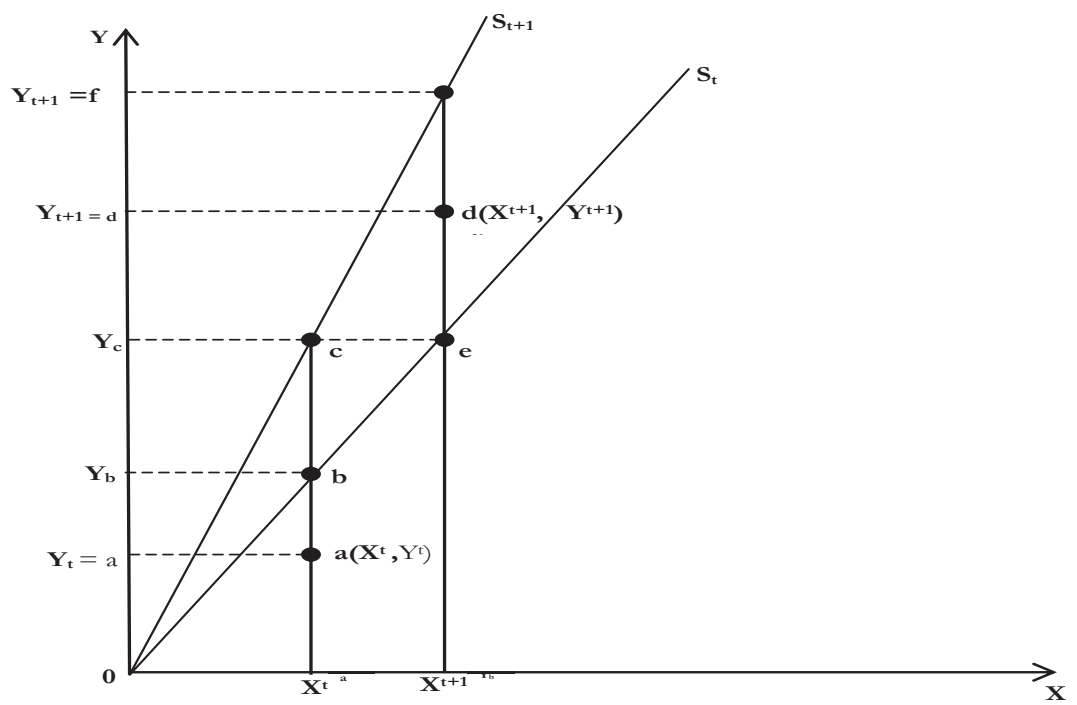

Figure 1: A Malmquist Productivity Index.

Source: Adopted from Mawson et al, 2003

Technological change is captured by a shift of the production frontier from $\mathrm{S}_{\mathrm{t}}$ to $\mathrm{S}_{\mathrm{t}+1}$ over time. The two Constant Returns to Scale (CRS) production frontiers $\left(S_{t}\right.$ and $\left.S_{t+1}\right)$, represent the technology available in periods $t$ and $\mathrm{t}+1$. The production frontiers indicate the various input-output combinations that were produced by a Decision Making Unit (DMU) across the two production periods, $t$ and $t+1$. In the first period $t$, a DMU utilized $X_{t}$ units of inputs and produced output levels $Y_{t}=a$. In the second period $t+1$, the DMU used $X_{t+1}$ inputs to produce $\mathrm{Y}_{\mathrm{t}+1}=\mathrm{d}$ output. During the two periods the output levels realized by the DMU were below what should have been efficiently produced. There was therefore technical inefficiency in both periods (Mawson et al, 2003). To compute the technical efficiency change component of a DMU we construct two distance functions: $d_{o}{ }^{t+1}$ $\left(\mathrm{X}^{\mathrm{t}+1}, \mathrm{Y}^{\mathrm{t}+1}\right)$ and $\mathrm{d}_{\mathrm{o}}{ }^{\mathrm{t}}\left(\mathrm{X}^{\mathrm{t}}, \mathrm{Y}^{\mathrm{t}}\right)$. The distance functions reveal how close or far the actual output levels produced are from the best practice frontier during the two periods, $\mathrm{t}$ and $\mathrm{t}+1$.

The distance functions therefore represent the relative efficiency of a DMU. From Figure 1, $\mathrm{d}_{0}{ }^{\mathrm{t}}\left(\mathrm{X}^{\mathrm{t}}, \mathrm{Y}^{\mathrm{t}}\right)=$ $\mathrm{a} / \mathrm{b}$ because the actual output level during period $\mathrm{t}$ was $\mathrm{Y}_{\mathrm{t}}=\mathrm{a}$ yet if the DMU had been technically efficient, it would have produced output level b. Analogously $\mathrm{d}_{\mathrm{o}}^{\mathrm{t}+1}\left(\mathrm{X}^{\mathrm{t}+1} ; \mathrm{Y}^{\mathrm{t}+1}\right)=\mathrm{d} / \mathrm{f}$ and hence the technical efficiency change component during periods $\mathrm{t}$ and $\mathrm{t}+1$ is expressed as follows:

$$
\frac{d / f}{a / b} \frac{d}{f} \frac{b}{a}
$$

To calculate the technological change component of the DMU we compute: $d_{o}^{t}\left(X^{t+1}, Y^{t+1}\right)$ and $d_{o}^{t+1}\left(X^{t}, Y^{t}\right) . d_{o}^{t}$ $\left(\mathrm{X}^{\mathrm{t}+1}, \mathrm{Y}^{\mathrm{t}+1}\right)$. The computed metric measures how close or far the actual output levels for period $\mathrm{t}+1$ is to the maximum output that could have been produced with $\mathrm{X}_{\mathrm{t}+1}$ inputs had period t's technology been available.

$\mathrm{d}_{\mathrm{o}}{ }^{\mathrm{t}}\left(\mathrm{X}^{\mathrm{t}+1}, \mathrm{Y}^{\mathrm{t}+1}\right)=\mathrm{d} / \mathrm{e} . \quad \mathrm{d}_{\mathrm{o}}^{\mathrm{t}}\left(\mathrm{X}^{\mathrm{t}+1}, \mathrm{Y}^{\mathrm{t}+1}\right)$ can exceed unity (and has actually exceeded unity) if technological advancement has occurred. $\mathrm{d}_{\mathrm{o}}{ }^{\mathrm{t}}\left(\mathrm{X}^{\mathrm{t}+1}, \mathrm{Y}^{\mathrm{t}+1}\right)$ measures how close the level of output actually produced in period $\mathrm{t}$ is to the maximum output level that could have been produced from period t's inputs had $t+1$ 's technology been available. $\mathrm{d}_{\mathrm{o}}{ }^{\mathrm{t}}\left(\mathrm{X}^{\mathrm{t}+1}, \mathrm{Y}^{\mathrm{t}+1}\right)=\mathrm{a} / \mathrm{c}$. The technological change component is therefore expressed as follows:

$$
\left[\left[\frac{d / e}{d / f}\right] *\left[\frac{a / b}{a / c}\right]\right]^{1 / 2}=\left[\left[\frac{f}{g}\right] *\left[\frac{c}{b}\right]\right]^{1 / 2}
$$

The total factor productivity growth is therefore a product of technical efficiency change and technological change (X.Y) (Malmquist, 1953; Mawson et al, 2003).

\section{Empirical Literature Review}

Measuring the teaching and research productivity of higher education institutions has taken different forms and has been a major focus of researchers. Many studies have been conducted to examine various aspects of the productivity of faculty members, academic departments and entire higher education institutions. Different researchers have used different methodologies to measure the productivity of higher education institutions. For purposes for this research only a few selected empirical studies are reviewed based on similarity of methodologies used for ease of comparisons and discussion of results. The literature review focuses of entire 
universities as the decision making units.

Sav (2012) revealed a technical efficiency change regress for USA public research and doctoral granting universities during the academic years, 2005-2009. The average malmquist index was 0.987 implying a productivity regress of 0.13 which was attributed more to technical efficiency change, 0.984 than to technological change of 1.003. Technical efficiency regress was, however, mainly a result of pure managerial inefficiency, 0.987 rather than scale inefficiency of 0.997. Managerial decision making in the allocation of resources was therefore the largest contributor to university productivity regress of USA research and doctoral granting universities. Poor technological and inefficiency experienced by USA research and doctoral granting universities were attributed to the long lasting effects of the 2005 devastation brought about by the Hurricane Katrina. Sav (2012), however, argued against downsizing since the recession effects would easily be offset by the improved performance of the American economy.

In related studies, Castano \& Cabanda (2007) indicated that the teaching productivity gains of Philippines State Universities and Colleges (SUCs) were largely a result of technical efficiency rather than technological progress/modern teaching and learning facilities over the period, 1999-2003. The SUCs registered a MPI score of 1.002 implying a productivity growth of $2 \%$. The technological index indicated that only six or $10.6 \%$ of the SUCs had a technological progress and 43 SUCs experienced technological regress.

Worthington \& Lee $(2008)$ asserted that whereas the research productivity gains were associated more with improvements in efficiency, the teaching gains of Australian universities were mainly due to technological gains rather than efficiency improvements. The research-only and teaching-only models reflected average productivity growths of $6.3 \%$ and $2.9 \%$, respectively. The largest productivity improvements were registered in the smaller, newer universities rather than the larger \& older universities because the smaller \& newer universities exploited the primary sources of productivity gains which the older universities could have exhausted and their productivity could have started to slow down.

Garcia-Aracil \& Navarro-Milla (2006) and Garcia-Aracil \& Lopez-Inesta (2006) indicated that the productivity growth of Spanish public universities was majorly a result of technological progress rather than efficiency progress. Garcia-Aracil \& Navarro-Milla (2006) attributed the productivity growth for Spanish public universities largely to research gains while Garcia-Aracil \& Lopez-Inesta (2006) tagged it more to knowledge transfer other than to research. Spanish public universities posted a productivity indices of $12.4 \%$ for the knowledge transfer-only model, $5.4 \%$ for research-only model and $0.5 \%$ for teaching- only model. The increase in research productivity was mainly a result of efficiency gains while teaching losses were mainly due to technological deterioration.

$\mathrm{Ng} \& \mathrm{Li}$ (2006) revealed that Chinese Coastal region universities produced more teaching and research outputs than non-costal universities because they received larger amounts of all inputs than non-coastal universities. The negative productivity growth resulted in a decline in efficiency overtime and technological regression among non-coastal universities. The discrepancy between the poor universities and the best performers widened i.e. there was no catching-up effect. The non-coastal universities were less exposed to market forces and found it harder to access external sources of funds or other resources.

In a related study, Agasisti and Perez-Esparrells (2009) indicated that Italian universities were more productive (1.482) than Spanish universities (1.063) under the DEA VRS option. The productivity change of Italian universities was mainly a result of technological progress, 1.388 as opposed to technical efficiency change of 1.070. The productivity change of Spanish universities was, however, attributed more to technical efficiency change, 1.230 than to technological progress of 0.859 . Italian and Spanish universities combined produced a mean efficiency score of 0.739 . Most Spanish universities operated in IRS region while many Italian universities experienced DRS.

\section{Materials and Methods}

The DEA-Based Malmquist Productivity Index (MPI) technique is applied to investigate the total factor productivity growth for the "general model", the "teaching-only" and "research-only" models. This approach is a particularly attractive method since it does not require knowledge of input and output prices, nor does it require any specific behavioral assumptions of the DMUs under consideration, such as cost minimization or profit or revenue maximization (Worthington \& Lee, 2005). The Malmquist Productivity Index was first introduced by Malmquist (1953). It was further studied and developed in the non-parametric framework by Caves et al (1982), Fare et al (1994) and Cooper et al (2007). Fare et al (1992) allowed for technical inefficiency and identified technical change and technical efficiency as distinct components of productivity change. If we have a production function in time $t_{1}$ and $t_{2}$, the Malmquist Index calculation would require two single period and two mixed period measures. The two single period measures can be obtained using the CCR DEA model (Charnes et al, 1978). The first two functions are calculated by considering the technologies of period $t_{1}$ and successively the amounts of production factors in $t_{1}$ and $t_{2}$ i.e. $d_{0}^{t_{1}}\left(Y_{t_{1}}, X_{t_{1}}\right)$ and $d_{0}{ }^{t_{1}}\left(Y_{t_{2}}, X_{t_{2}}\right)$. We therefore obtain the first index of 
productivity as:

$$
M_{0}{ }^{t_{1}}\left(Y_{t_{2}}, X_{t_{2}}, Y_{t_{1}}, X_{t_{1}}\right)=\left[\frac{d_{o}{ }^{t_{1}}\left(y_{t_{2}}, X_{t_{2}}\right)}{d_{0}{ }^{t_{1}}\left(y_{t_{1}}, X_{t_{1}}\right)}\right]
$$

Equation 1 represents the productivity point $\left(X_{t_{2}}, Y_{t_{2}}\right)$ relative to the production point $\left(X_{t_{1}}, Y_{t_{1}}\right)$. Analogously, two other factors are calculated by considering technologies of period $t_{2}$ with amounts of production factors in $t_{1}$ then $t_{2}$ such as: $d_{0}{ }^{t_{2}}\left(Y_{t_{1}}, X_{t_{1}}\right)$ and $d_{0}{ }^{t_{2}}\left(Y_{t_{2}}, X_{t_{2}}\right)$. We obtain as such before productivity index such as:

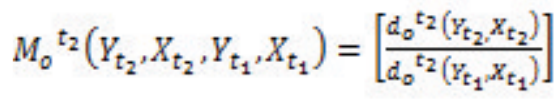

The two indexes appear to be the identical; they may or may not be the same in the case of varying returns to scale (VRS) technology. In order to avoid choosing an arbitrary benchmark or technology reference, Fare et al (1994) specifies the Malmquist index of total factor productivity as a geometric mean of the two preceding indices. A Malmquist Productivity Index between periods: $t_{1}$ and $t_{2}, t_{1}<t_{2}$ can therefore be defined as:-

$$
M_{0}{ }^{t_{2}, t_{1}}\left(Y_{t_{2}}, X_{t_{2}}, Y_{t_{1}}, X_{t_{1}}\right)=\left[\left[\frac{d_{0}{ }^{t_{1}}\left(y_{t_{2}}, x_{t_{2}}\right)}{d_{0}{ }^{t_{1}}\left(y_{t_{1}}, x_{t_{1}}\right)}\right] *\left[\frac{d_{0}{ }^{t_{2}}\left(y_{t_{2}}, x_{t_{2}}\right)}{d_{0}{ }^{t_{2}}\left(y_{t_{1}}, X_{t_{1}}\right)}\right]\right]^{1 / 2}
$$

Under the Caves, Christensen and Diewert (CCD) (1982) it is assumed there is no technical inefficiency and hence $d_{0}{ }^{t_{2}}\left(Y_{t_{1}}, X_{t_{1}}\right)=d_{0}{ }^{t_{2}}\left(Y_{t_{2}}, X_{t_{2}}\right)=1$. It is, however, common that some degree of inefficiency exists in DMUs hence it is more realistic to assume that $d_{0}{ }^{t_{2}}\left(Y_{t_{1}}, X_{t_{1}}\right) \leq 1$ and $d_{0}{ }^{t_{2}}\left(Y_{t_{2}}, X_{t_{2}}\right) \leq 1$. If inefficiency exists Fare et al (1992) decomposes equation 3 into the product of technical efficiency ("catching up") and technical change hence Equation 3 is rewritten as:-

$$
M_{0}{ }^{t_{2}, t_{1}}\left(Y_{t_{2}}, X_{t_{2}}, Y_{t_{1}}, X_{t_{1}}\right)=\frac{d_{0}{ }^{t_{2}}\left(y_{t_{2}}, x_{t_{2}}\right)}{d_{0}{ }^{t_{1}}\left(y_{t_{1}}, x_{t_{1}}\right)}\left[\left[\frac{d_{0}{ }^{t_{1}}\left(y_{t_{2}}, x_{t_{2}}\right)}{d_{0}{ }^{t_{2}}\left(y_{t_{2}}, x_{t_{2}}\right)}\right] *\left[\frac{d_{0}{ }^{t_{1}}\left(y_{t_{1}}, x_{t_{1}}\right)}{d_{0}{ }^{t_{2}}\left(y_{t_{1}}, x_{t_{1}}\right)}\right]\right]^{1 / 2} \ldots \ldots \ldots \ldots \ldots \ldots \ldots . . .4
$$

Technological change

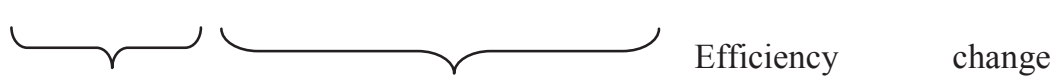

Where: ${ }^{M_{0}}=$ Malmquist Productivity Index; $d_{o}=$ Distance Function; $\left(Y_{t_{2}}, X_{t_{2}}\right)=$ Represents the production point of the productivity; $\left(Y_{\mathrm{t}_{\mathrm{s}}}, X_{\mathrm{t}_{\mathrm{t}}}\right)=$ Relative production point of productivity; $\mathrm{t}_{1}=$ Period of benchmark technology and $\mathrm{t}_{2}=$ The next period of technology

The DEAP 2.1 Computer Software program developed by Coelli, 1996 was used to estimate the total factor productivity growth of African public universities posted five indices in its output file:

(a) Technical efficiency change relative to CRS technology (efficiency change), Effch. Technical efficiency change reflects the convergence towards or divergence from the best practice frontier. An improvement in technical efficiency change is the "catch-up" term. A technical efficiency change index greater than 1 depicts the capability of the university in satisfying the production limit.

(b) Technological change (frontier shifts), technical change, Techch. Technological change reflects improvements or stagnation or decline in the performance of best practice universities. Improvement in the technological change is a shift in the best practice frontier. Technologic change index being greater than unity means the university was successful in hoisting its efficiency level.

Personnel's knowledge and the flow of personnel directly influence the average technical strength of universities. If universities lose high level personnel and do not replace them to bridge the gap, the average technical level of the universities will descend. Technical regress could be attributed to the outflow of key personnel from universities.

(c) Pure technical efficiency change relative to a VRS technology, Pech. Pure technical inefficiency is a reflection of the scope for inefficiency resulting from less efficient work practices, inadequate processes and poor management but may also reflect differences between operating environment. Decrease in pure technical efficiency signals the distortion in managerial competence.

(d) Scale efficiency change, Sech. Scale efficiency captures the deviation between the VRS and CRS technologies. The CCR efficiency takes into account the fact that DMUs operate at scales that are not their Most Productive Scale Size (MPSS). The MPSS (Banker, 1984) implies that a decision making unit's production of outputs is maximized per unit of inputs i.e. scale elasticity is equal to 1 . There is only one MPSS i.e. where the scale of efficiency is a maximum at $100 \%$. The VRS option takes into account the variation of efficiency with respect to scale of production and hence measures pure technical efficiency. 
(e) Total factor productivity change, Tfpch. It measures the technical and productivity changes over time. Malmquist index greater than 1 indicates an improvement or progress of the total factor productivity from period 1 to period 2. If MPI $=1$, it implies the status quo or invariance of productivity change. A deterioration in the total factor productivity change exists if MPI $<1$ (Ramanathan; 2003).

The abbreviations: Effch for Technical efficiency change, Techch for Technological change, Pech for Pure technical efficiency, Sech for Scale efficiency and Tfpch for Total factor productivity change/growth are used in Table 3, Table 4, Table 5, Table 6, Table 7 and Table 8. Two things are emphasized regarding the efficiency, technology and productivity indices: (i) the indices and any resulting percentage changes are relative which means that a university may be more or less efficient, or more or less productive only in reference to other universities in the study sample and (ii) productivity is also relative in the sense that a larger university could be more productive (producing more outputs) but its productivity may be low in relation to the inputs employed (Worthington and Lee, 2008).

\subsection{Unit of Analysis}

The units of analysis are 15 African public universities. The study follows Smith \& Street (2006) who assert that unit of analysis should: (i) capture the entire production process of interest, (ii) be a decision making unit and (iii) the sample units should be seeking to produce similar outputs.

\subsection{Data Sources and Sample Size}

Panel data used to estimate the total factor productivity growth of 15 African public universities in during the period; 2000-2007 were obtained from the Centre for Higher Education Transformation (CHET) and the Higher Education Management Information System (HEMIS) of the Department of Higher Education and Training, Republic of South Africa. In a DEA model; three variables: the number of inputs (p), the number of outputs (q) and number of DMUs (n) are important in determining the sample size. The study followed Cooper, Seiford and Tone (2000) who argue that a rough rule of thumb for determining the sample size for a DEA model is as follows: $\mathrm{n} \geq \operatorname{Max}\{\mathrm{pxq} ; 3(\mathrm{p}+\mathrm{q})\}$. The literature is, however, littered with studies where DEA has been applied on small samples (Ramanathan, 2003). Charnes et al (1978) assert that all input-output data of DMUs should strictly be positive.

\subsection{Choice of Input and Output Variables}

Public universities have multiple objectives and use multiple inputs to produce multiple outputs (Kosor, 2013). In selecting the variables, the study followed Wolszak-Derlacz \& Parteka (2011) and Garcia- Arcil \& NavarroMilla (2006). Staff and student enrolments are employed as inputs variables while graduation numbers and Institute of Scientific Information (ISI) papers are used research output variables. University staff are broadly categorized as teaching and non-teaching staff. Student enrolments and graduation numbers are disaggregated into: undergraduate and postgraduates. The separation of doctorates amplifies the variation across African public universities in production of doctorates which is a proxy for the research capacity of a university (Kantabutra and Tang, 2010). Doctoral graduates form the core of the academia and researchers needed by both universities and other sectors of the economy. The inputs and outputs used in estimating total factor productivity growth of African public universities are presented in Table 1.

Table 1: Definition of Variables for estimating Malmquist Indices

\begin{tabular}{|l|l|}
\hline Input Variables & Description \\
\hline 1. Student Enrolments & $\begin{array}{l}\text { Total number of students enrolled in a university disaggregated into } \\
\text { Undergraduates, Post graduates up to Masters level and PhDs/Doctorates }\end{array}$ \\
\hline 2.Staffing Levels & $\begin{array}{l}\text { Total number of university staff disintegrated into teaching \& non-teaching } \\
\text { categories }\end{array}$ \\
\hline Output Variables & \\
\hline $\begin{array}{l}\text { 3.Graduation/Completion } \\
\text { numbers }\end{array}$ & $\begin{array}{l}\text { Total number of university graduates disaggregated into Undergraduate ,Post } \\
\text { graduates up to Masters level and PhDs/Doctorates }\end{array}$ \\
\hline 4.Research outputs & Total university research output; ISI Papers and Doctoral Graduates/PhDs \\
\hline
\end{tabular}

\subsection{Model Specifications}

The identification of inputs and outputs to include in a particular application of a DEA Model is contextualized differently by researchers (Norman and Stocker, 1991). Pastor et al (2001) is adopted to estimate an outputorientated DEA-Based Malmquist Indices for the general, teaching-only and research-only models. The VRS options are adopted because: (i) it is difficult to change the scale of operation of universities in the short run, (ii) 
the selected universities are of variant sizes and (iii) it allows scales of economies to change as the size of universities change (Carrington et al, 2005). A sensitivity analysis of the preferred models is conducted by verifying the extent to which their efficiency mean scores are affected by the omission or addition of an input variable (s) since the output variables are fixed for all three models (Cooper et al, 2007).

4.4.1 General Model Specifications

The General Model is built on the premise that universities produce both graduates and research outputs (Lehmann \& Warning, 2002). Total graduation numbers and total research outputs are the two fixed output variables with which different sets of inputs are coupled to estimate Malmquist Indices of African public universities. Input and output combinations applied to the General Model specifications are presented in Table 2.

Table 2: General Model Specifications

\begin{tabular}{|c|c|c|c|c|c|c|c|c|c|c|c|}
\hline & General Model Specifications & 1 & 2 & 3 & 4 & 5 & 6 & 7 & 8 & 9 & 10 \\
\hline & Input Variables & & & & & & & & & & \\
\hline $\mathrm{X} 1$ & Undergraduate Enrolments & $\mathrm{x}$ & $\mathrm{x}$ & $\mathrm{x}$ & & & & & & & \\
\hline $\mathrm{X} 2$ & Postgraduate Enrolments up to Masters level & $\mathrm{x}$ & $\mathrm{x}$ & $\mathrm{x}$ & & & & & & & \\
\hline $\mathrm{X} 3$ & Total Enrolments & & & & $\mathrm{x}$ & $\mathrm{x}$ & $\mathrm{x}$ & $\mathrm{x}$ & & & \\
\hline $\mathrm{X} 4$ & Doctoral Enrolments & $\mathrm{x}$ & & & $\mathrm{x}$ & & & & $\mathrm{x}$ & $\mathrm{x}$ & $\mathrm{x}$ \\
\hline $\mathrm{X} 5$ & Total Number of Teaching Staff & & $\mathrm{x}$ & & & & $\mathrm{x}$ & $\mathrm{x}$ & $\mathrm{x}$ & $\mathrm{x}$ & \\
\hline $\mathrm{X} 6$ & Total Number of Non-Teaching Staff & & & $\mathrm{x}$ & & & $\mathrm{x}$ & & $\mathrm{x}$ & & $\mathrm{x}$ \\
\hline \multirow[t]{2}{*}{$\mathrm{X} 7$} & Total Staff & & & & $\mathrm{x}$ & $\mathrm{x}$ & & & & & \\
\hline & Output Variables & & & & & & & & & & \\
\hline Y3 & Total Graduations Numbers & $\mathrm{x}$ & $\mathrm{x}$ & $\mathrm{x}$ & $\mathrm{x}$ & $\mathrm{x}$ & $\mathrm{x}$ & $\mathrm{x}$ & $\mathrm{x}$ & $\mathrm{x}$ & $\mathrm{x}$ \\
\hline Y6 & Total Research Outputs & $\mathrm{x}$ & $\mathrm{x}$ & $\mathrm{x}$ & $\mathrm{x}$ & $\mathrm{x}$ & $\mathrm{x}$ & $\mathrm{x}$ & $\mathrm{x}$ & $\mathrm{x}$ & $\mathrm{x}$ \\
\hline
\end{tabular}

Model 5 is selected as the preferred general model because it meets the stipulated criteria:

(a) Charnes et al (1989) heuristic for the DEA that restricts the total number of variables to include in the various model specifications to four.

(b) Fixed output variables reflect the two basic core functions of a university which are teaching (total graduation numbers) and research (total research outputs) and

(c) The model includes the vital university inputs which are total student enrolments and total staff (Worthington and Lee, 2008)

\subsubsection{Teaching-Only Model Specifications}

The teaching-only model is built on the premise that universities employ academic staff to teach students enrolled to produce graduates as outputs (Kuah \& Wong, 2011). Total undergraduate and total postgraduate graduation numbers are the output variables used to estimate Malmquist Indices for teaching-only model since the input variable specifications for the general model in Table $\mathbf{2}$ are the same for the teaching-only model. Model 7 is selected as the preferred teaching-only model because it meets the set criteria:

(a) Charnes et al (1989) heuristic for the DEA that restricts the total number of variables to include in the various model specifications to four;

(b) Fixed output variables that reflect the teaching function of a university are total undergraduate graduation numbers and total postgraduate graduation number and

(c) The model includes the vital university teaching inputs which are total student enrolments and total number of teaching staff (Worthington and Lee, 2008).

\subsubsection{Research-Only Model Specification}

The Research-Only Model is built on the premise that academic staff with doctorates and doctoral enrolments are the main inputs while doctoral graduates and publications are the main high level knowledge outputs (CHET, 2013). Total doctoral graduation numbers and ISI papers are the two fixed research output variables with which different sets of input-variables in Table 2 are coupled to estimate Malmquist Indices for the Research-Only Model. Model 9 is selected as the preferred Research-Only DEA Model because it fulfils the set selection criteria:

(a) Charnes et al (1989) heuristic for the DEA that restricts the total number of variables to include in the standard DEA specifications to four.

(b) The CHET (2013) criteria which considers:

(i) Academic staff (with PhDs/Doctorates) and doctoral enrolments are the main inputs into a university's high level knowledge production and Doctoral graduates and research publications as the main high level knowledge outputs (Boshof, 2010).

\subsection{Adjusting the operating environment for African Public Universities}

The operating environment of African public universities is adjusted for in two ways: (i) compare only decision making units which operate in a similar environment. The disadvantage with this approach is that the number of 
universities to compare will reduce and yet the main lessons to learn may come from decision making units operating in dissimilar environment and (ii) compare only universities operating in similar or less favorable operating conditions. The pitfalls of the preceding option are addressed but it ignores potential lessons from decision making units operating in more favorable conditions (Common Wealth of Australia, 1997). To adjust for the operating environment, the study adopted Bailey, Cloete \& Pillay (2012) clustering of African universities. The first sub-group of universities; Cluster A is built of the premise of comparing only universities operating in similar or less favorable operating conditions while Cluster B is built on the premise of comparing only universities that operate in a similar environment. The universities in Cluster A and Cluster B are listed in Tables 6.

\section{Empirical Results}

The DEA-Based Malmquist Indices for the general, teaching-only and research-only models were computed using the DEAP Version 2.1 Computer Software developed/written by Coelli, 1996. There is no direct way of assessing whether the Malmquist Indices are statistically significant or not and hence some form of sensitivity analysis is conducted by verifying how the mamlquist productivity indices retort when input or output variables are introduced or withdrawn from a set of DMUs under consideration. The study followed Pastor et al (2001) who establish the extent to which a variable not included in the DEA model would improve the malmquist productivity indices when included. The methodology therefore involves comparing the malmquist productivity indices of the reduced model with those of the extended/augmented/total model. Care was taken to avoid model misspecifications especially for the preferred models which is majorly a result of inclusion of irrelevant variables, omission of relevant variables, and or incorrect assumptions (Worthington \& Lee, 2008, Boshoff, 2010). Due to space constraints only results of the preferred and adjusted preferred models are presented.

\subsection{The Preferred General Model}

Annual means for the preferred and adjusted preferred models are not presented because they do not show the malmquist indices for the individual universities yet they are the subject matter of investigation. The Malmquist Indices of African public universities for the Preferred General DEA Model are presented in Table 3.

Table 3: Preferred General Model Malmquist Index Summary of African Universities

\begin{tabular}{|l|l|l|l|l|l|}
\hline Decision Making Units & Effch & Techch & Pech & Sech & Tfpch \\
\hline 1. Makerere University & 0.909 & 1.042 & 1.054 & 0.863 & 0.948 \\
\hline 2. University of Mauritius & 0.961 & 1.051 & 1.009 & 0.953 & 1.01 \\
\hline 3. University of Ghana & 0.969 & 1.057 & 1.059 & 0.915 & 1.024 \\
\hline 4. University of Botswana & 0.947 & 1.101 & 0.965 & 0.982 & 1.042 \\
\hline 5. University of Nairobi & 0.981 & 1.027 & 1.001 & 0.98 & 1.008 \\
\hline 6. University of Dar es Salaam & 1.006 & 1.278 & 1.006 & 1 & 1.286 \\
\hline 9. University of Western Cape & 0.991 & 1.043 & 0.975 & 1.016 & 1.033 \\
\hline 10. University of the Free State & 0.973 & 1.075 & 0.975 & 0.998 & 1.046 \\
\hline 11. University of Witwatersrand & 0.983 & 1.057 & 0.984 & 0.999 & 1.039 \\
\hline 12. University of Limpopo & 1.005 & 1.136 & 1.004 & 1.001 & 1.141 \\
\hline 13. Rhodes University & 1.009 & 1.218 & 1.004 & 1.005 & 1.229 \\
\hline 14. University of Fort Hare & 1.023 & 1.156 & 1.018 & 1.005 & 1.183 \\
\hline 15. University of Cape Town & 1.008 & 1.123 & 1 & 1.008 & 1.132 \\
\hline Mean & $\mathbf{0 . 9 8}$ & $\mathbf{1 . 0 9 8}$ & $\mathbf{1 . 0 0 1}$ & $\mathbf{0 . 9 7 9}$ & $\mathbf{1 . 0 7 5}$ \\
\hline
\end{tabular}

African public universities registered a mean total factor productivity growth of 1.075 implying a $7.5 \%$ growth rate over the eight years period. The total factor productivity growth is, however, mainly attributed to technological change of $9.8 \%$ rather than technical efficiency change; $-20 \%$. The technical efficiency deterioration was, however, mainly a result of scale inefficiency, $-21 \%$ rather than pure technical efficiency of $0.1 \%$. African public university managers hence marginally utilized total student enrolments and total staff to produce graduates and research outputs. The negative efficiency change implies that there is no catching up effect between the more productive and less productive universities.

\subsection{The Preferred Teaching-Only Model}

The teaching Malmquist Indices for the African public universities are presented in Table 4. 
Table 4: Preferred Teaching-Only Model Malmquist Index Summary of African Universities

\begin{tabular}{|l|l|l|l|l|l|}
\hline Decision Making Units & Effch & Techch & Pech & Sech & Tfpch \\
\hline 1. Makerere University & 0.958 & 0.899 & 1.049 & 0.913 & 0.861 \\
\hline 2. University of Mauritius & 1.010 & 0.953 & 1.021 & 0.990 & 0.963 \\
\hline 3. University of Ghana & 0.996 & 0.927 & 1.054 & 0.945 & 0.924 \\
\hline 4. University of Botswana & 0.986 & 0.949 & 0.985 & 1.000 & 0.935 \\
\hline 5. University of Nairobi & 1.024 & 0.979 & 1.011 & 1.013 & 1.002 \\
\hline 6. University of Dar es Salaam & 1.007 & 1.009 & 1.000 & 1.007 & 1.016 \\
\hline 7. Nelson Mandela Metropolitan University & 0.974 & 0.987 & 0.974 & 1.000 & 0.961 \\
\hline 8. University of Kwa Zulu Natal & 0.970 & 1.002 & 0.981 & 0.989 & 0.971 \\
\hline 9. University of Western Cape & 1.003 & 0.974 & 0.983 & 1.020 & 0.977 \\
\hline 10. University of the Free State & 1.022 & 1.009 & 0.987 & 1.035 & 1.031 \\
\hline 11. University of Witwatersrand & 0.990 & 0.972 & 0.994 & 0.996 & 0.962 \\
\hline 12. University of Limpopo & 1.002 & 1.088 & 0.997 & 1.005 & 1.090 \\
\hline 13. Rhodes University & 1.000 & 1.138 & 1.000 & 1.000 & 1.138 \\
\hline 14. University of Fort Hare & 1.009 & 1.160 & 1.010 & 0.999 & 1.170 \\
\hline 15. University of Cape Town & 0.989 & 1.158 & 0.991 & 0.998 & 1.146 \\
\hline Mean & $\mathbf{0 . 9 9 6}$ & $\mathbf{1 . 0 1 1}$ & $\mathbf{1 . 0 0 2}$ & $\mathbf{0 . 9 9 4}$ & $\mathbf{1 . 0 0 7}$ \\
\hline
\end{tabular}

African public universities registered a mean total factor productivity growth of 1.007 implying $0.7 \%$ growth rate in the teaching function during the eight years period. The teaching gains for African public universities are attributed to technological change, $1.1 \%$ rather than to technical efficiency change of $-4 \%$. Technical inefficiency regress of the African public universities was, however, mainly a result of scale inefficiency, $-6 \%$ rather than pure technical efficiency of $0.2 \%$. African public universities theoretically employed more resources; student enrolments and teaching staff to produce the current numbers of graduates.

\subsection{The Preferred Research-Only Model}

The total factor productivity growth of the Research-Only Model for the 15 African public universities is estimated. The research Malmquist Indices for the individual African public universities are presented in Table 5.

Table 5: Malmquist Index Summary for Preferred Research-Only Model

\begin{tabular}{|l|l|l|l|l|l|}
\hline Decision Making Units & Effch & Techch & Pech & Sech & Tfpch \\
\hline 1. Makerere University & 1.014 & 1.102 & 0.946 & 1.072 & 1.118 \\
\hline 2. University of Mauritius & 1.069 & 1.018 & 1.000 & 1.069 & 1.088 \\
\hline 3. University of Ghana & 1.028 & 1.116 & 1.041 & 0.987 & 1.147 \\
\hline 4. University of Botswana & 0.851 & 1.100 & 0.852 & 0.999 & 0.936 \\
\hline 5. University of Nairobi & 0.992 & 1.158 & 0.993 & 1.000 & 1.149 \\
\hline 6. University of Dar es Salaam & 0.985 & 1.176 & 0.994 & 0.991 & 1.159 \\
\hline 7. Nelson Mandela Metropolitan University & 1.000 & 1.121 & 1.000 & 1.000 & 1.121 \\
\hline 8. University of Kwa Zulu Natal & 0.908 & 1.118 & 0.962 & 0.945 & 1.016 \\
\hline 9. University of Western Cape & 0.986 & 1.139 & 1.000 & 0.986 & 1.123 \\
\hline 10. University of the Free State & 0.931 & 1.050 & 0.944 & 0.987 & 0.978 \\
\hline 11. University of Witwatersrand & 1.042 & 1.000 & 1.016 & 1.025 & 1.042 \\
\hline 12. University of Limpopo & 1.050 & 1.044 & 1.042 & 1.008 & 1.096 \\
\hline 13. Rhodes University & 0.885 & 0.982 & 0.888 & 0.997 & 0.869 \\
\hline 14. University of Fort Hare & 0.976 & 1.031 & 0.981 & 0.995 & 1.006 \\
\hline 15. University of Cape Town & 1.022 & 1.191 & 1.011 & 1.011 & 1.217 \\
\hline Mean & $\mathbf{0 . 9 8 2}$ & $\mathbf{1 . 0 8 8}$ & $\mathbf{0 . 9 7 7}$ & $\mathbf{1 . 0 0 4}$ & $\mathbf{1 . 0 6 8}$ \\
\hline
\end{tabular}

The research total factor productivity growth of 1.068 for the African public universities is mainly attributed to technological change, $8.8 \%$ rather than technical efficiency change, $-18 \%$. A pure technical efficiency deterioration of $-23 \%$ is registered. African university managers did not properly allocate facilities and resources towards the research function and hence were the major reason for the low research productivity of the African public universities. African public universities, however, took advantage of technological advancements like increased Internet connectivity and online referred journals to increase their research outputs.

5.4 The Adjusted Preferred General Model

Malmquist Indices for the Adjusted Preferred General Mode1 are presented in Table 6. 
Table 6: Malmquist Index Summary for Adjusted Preferred General Model

\begin{tabular}{|l|l|l|l|l|l|}
\hline Decision Making Units & Effch & Techch & Pech & Sech & Tfpch \\
\hline Cluster A Universities & & & & & \\
\hline 1. Makerere University & 1.028 & 1.144 & 1.000 & 1.028 & 1.177 \\
\hline 2. University of Mauritius & 1.072 & 1.137 & 1.004 & 1.067 & 1.219 \\
\hline 3. University of Botswana & 1.031 & 1.120 & 1.000 & 1.030 & 1.154 \\
\hline 4. University of Dar es Salaam & 1.007 & 1.161 & 1.000 & 1.007 & 1.169 \\
\hline 5. University of Witwatersrand & 1.012 & 1.115 & 0.995 & 1.017 & 1.128 \\
\hline 6. University of Limpopo & 1.006 & 1.127 & 1.000 & 1.006 & 1.134 \\
\hline 7. Rhodes University & 1.007 & 1.095 & 1.002 & 1.005 & 1.102 \\
\hline 8. University of Cape Town & 1.000 & 1.121 & 1.000 & 1.000 & 1.121 \\
\hline Mean & 1.020 & 1.127 & 1.000 & 1.020 & 1.150 \\
\hline Cluster B Universities & & & & & \\
\hline 1. University of Ghana & 0.924 & 0.960 & 1.000 & 0.924 & 0.887 \\
\hline 2. University of Nairobi & 0.909 & 1.025 & 0.985 & 0.923 & 0.931 \\
\hline 3. Nelson Mandela Metropolitan University & 0.976 & 1.055 & 1.016 & 0.961 & 1.030 \\
\hline 4.University of Kwa Zulu Natal & 0.973 & 1.202 & 0.978 & 0.994 & 1.169 \\
\hline 5.University of Western Cape & 0.998 & 1.181 & 1.007 & 0.992 & 1.179 \\
\hline 6.University of the Free State & 1.003 & 1.293 & 1.000 & 1.003 & 1.297 \\
\hline 7.University of Fort Hare & 1.000 & 1.163 & 1.000 & 1.000 & 1.163 \\
\hline Mean & 0.968 & 1.120 & 0.998 & 0.970 & 1.085 \\
\hline
\end{tabular}

Cluster A universities registered a mean total factor productivity growth of 1.150 implying a $15 \%$ growth rate in the teaching and research functions combined. Total factor productivity growth for Cluster A universities is mainly attributed to technological progress, $12.7 \%$ rather than technical efficiency change of $2 \%$. Technical efficiency change was, however, mainly a result of scale efficiency, $2 \%$ since there was pure technical efficiency stagnation. Cluster B universities registered a mean total factor productivity growth of 1.085 implying a $8.5 \%$ growth rate over the study period. The total factor productivity growth of Cluster B universities is also attributed more to technological progress, $12 \%$ rather than to technical efficiency deterioration of $-32 \%$. The technical efficiency deterioration of Cluster B universities was attributed more to scale inefficiency of $-30 \%$ rather than pure technical inefficiency of $-2 \%$.

The mean total factor productivity growth rate for Cluster A universities of $15 \%$ and Cluster B universities of $8.5 \%$ are higher than the total factor productivity growth rate of $7.5 \%$ for African Universities combined before adjusting for the operating environment. The operating environment is therefore a major factor in the teaching and research productivity of African public universities. Operating environment could include: physical location, age of universities, adequacy or inadequacy of funding, quality of inputs i.e. quality of students, staff and other support services etc. The negative pure technical efficiency implies that African public university managers need to improve the efficiency of their teaching and research processes in order to improve both the teaching and research productivity of the universities.

\subsection{The Adjusted Preferred Teaching-Only Model}

The Adjusted Preferred Teaching-only Model malmquist indices are presented in Table 7. 
Table 7: Malmquist Index Summary for the Adjusted Teaching-Only Model

\begin{tabular}{|l|l|l|l|l|l|}
\hline Decision Making Units & Effch & Techch & Pech & Sech & Tfpch \\
\hline Cluster A Universities & & & & & \\
\hline 1. Makerere University & 1.019 & 1.072 & 1.000 & 1.019 & 1.092 \\
\hline 2. University of Mauritius & 1.044 & 1.080 & 0.998 & 1.046 & 1.128 \\
\hline 3. University of Botswana & 1.029 & 1.069 & 0.998 & 1.031 & 1.100 \\
\hline 4. University of Dar es Salaam & 1.018 & 1.045 & 1.000 & 1.018 & 1.064 \\
\hline 5. University of Witwatersrand & 0.998 & 1.067 & 0.995 & 1.003 & 1.065 \\
\hline 6. University of Limpopo & 1.000 & 1.094 & 1.000 & 1.000 & 1.094 \\
\hline 7. Rhodes University & 0.994 & 1.086 & 0.996 & 0.998 & 1.080 \\
\hline 8. University of Cape Town & 0.991 & 1.086 & 0.996 & 0.955 & 1.076 \\
\hline Mean & 1.012 & 1.075 & 0.998 & 1.014 & 1.087 \\
\hline Cluster B Universities & & & & & \\
\hline 1. University of Ghana & 0.913 & 0.927 & 1.000 & 0.913 & 0.847 \\
\hline 2. University of Nairobi & 0.943 & 0.931 & 0.977 & 0.964 & 0.877 \\
\hline 3.Nelson Mandela Metropolitan University & 0.891 & 0.965 & 1.000 & 0.981 & 0.947 \\
\hline 4.University of Kwa Zulu- Natal & 0.979 & 1.081 & 0.995 & 0.984 & 1.059 \\
\hline 5.University of Western Cape & 1.025 & 1.077 & 1.023 & 1.002 & 1.103 \\
\hline 6.University of the Free State & 1.010 & 0.093 & 1.006 & 1.004 & 1.104 \\
\hline 7.University of Fort Hare & 0.992 & 1.136 & 0.992 & 1.000 & 1.127 \\
\hline Mean & 0.977 & 1.027 & 0.999 & 0.978 & 1.004 \\
\hline
\end{tabular}

Cluster A universities, registered a mean total factor productivity growth of 1.087 implying a $8.7 \%$ growth rate over the period, 2000-2007. The teaching total factor productivity growth of Cluster A universities is mainly attributed to technological progress; $7.5 \%$ rather than technical efficiency change of $1.2 \%$. Technical efficiency change is, however, attributed mainly to scale efficiency, $1.4 \%$ rather than pure technical inefficiency of $-2 \%$. Cluster B universities registered a mean teaching total factor productivity growth of 1.004 implying a $0.4 \%$ growth rate over the period, 2000-2007. The teaching total factor productivity growth rate is attributed more to technological progress of $2.7 \%$ rather than technical efficiency deterioration of $-2.3 \%$. The technical efficiency deterioration is, however, attributed more to scale inefficiency of $-2.2 \%$ rather than pure technical efficiency of $0.1 \%$. Both Cluster A and Club B universities embraced technological advancements in their teaching function. The implication of a negative pure technical efficiency for Cluster A universities is that university managements should optimize teaching resources like staff, students and other teaching inputs to make the universities more productive in their teaching function.

\subsection{The Adjusted Preferred Research-Only Model}

Research total factor productivity growth for Cluster A universities and Cluster B universities are separately estimated after adjusting for the operating environment. The adjusted Research-Only Model Malmquist Indices are presented in Table $\mathbf{8}$. 
Table 8: Research-Only Malmquist Index Summary for the Adjusted Model

\begin{tabular}{|l|l|l|l|l|l|}
\hline Decision Making Units & Effch & Techch & Pech & Sech & Tfpch \\
\hline Cluster A Universities & & & & & \\
\hline 1. Makerere University & 1.072 & 1.004 & 1.000 & 1.072 & 1.076 \\
\hline 2. University of Mauritius & 1.044 & 1.029 & 0.998 & 1.046 & 1.075 \\
\hline 3. University of Botswana & 1.042 & 1.071 & 0.998 & 1.044 & 1.116 \\
\hline 4. University of Dar es Salaam & 1.064 & 1.177 & 0.998 & 1.066 & 1.253 \\
\hline 5. University of Witwatersrand & 0.998 & 1.133 & 0.994 & 0.993 & 1.119 \\
\hline 6. University of Limpopo & 1.000 & 1.143 & 1.000 & 1.000 & 1.143 \\
\hline 7. Rhodes University & 0.997 & 1.085 & 1.000 & 0.998 & 1.082 \\
\hline 8. University of Cape Town & 1.000 & 1.178 & 1.000 & 1.000 & 1.178 \\
\hline Mean & $\mathbf{1 . 0 2 5}$ & $\mathbf{1 . 1 0 1}$ & $\mathbf{0 . 9 9 9}$ & $\mathbf{1 . 0 2 7}$ & $\mathbf{1 . 1 2 9}$ \\
\hline Cluster B Universities & & & & & \\
\hline 1. University of Ghana & 0.945 & 0.995 & 1.000 & 0.945 & 0.940 \\
\hline 2. University of Nairobi & 1.081 & 1.143 & 1.000 & 1.018 & 1.164 \\
\hline 3.Nelson Mandela Metropolitan University & 0.955 & 1.290 & 1.000 & 0.955 & 1.232 \\
\hline 4.University of Kwa Zulu Natal & 1.060 & 1.326 & 1.039 & 1.020 & 1.406 \\
\hline 5.University of Western Cape & 1.029 & 1.344 & 1.000 & 1.028 & 1.383 \\
\hline 6.University of the Free State & 0.985 & 1.398 & 0.994 & 0.991 & 1.377 \\
\hline 7.University of Fort Hare & 1.012 & 1.341 & 1.012 & 1.000 & 1.358 \\
\hline Mean & 1.000 & 1.255 & 1.006 & 0.993 & 1.255 \\
\hline The mean researh tota factor proding
\end{tabular}

The mean research total factor productivity growth, for Cluster A universities was 1.129 implying a $12.9 \%$ growth rate during the period, 2000-2007. The research total factor productivity growth of Cluster A universities was attributed more to technological progress, $10.1 \%$ than to technical efficiency change of $2.5 \%$. The mean total factor productivity growth rate of $12.9 \%$ is higher than the university specific total factor productivity growth rates for all Cluster A universities except for the University of Dar es Salaam, 25.3\%, University of Cape Town, $17.8 \%$ and University of Limpopo of $14.3 \%$. The research total factor productivity change for all Cluster B universities is 1.255 implying a $25.5 \%$ growth rate. Research total factor productivity growth of $25.5 \%$ after adjusting for the operating environment was entirely attributed to technological progress since there was technical efficiency stagnation. The technical efficiency stagnation for Cluster B universities, however, was attributed more scale inefficiency $-7 \%$ rather than pure technical efficiency change of $0.6 \%$. Both Cluster A and Club B universities embraced technological advancements in their research function but there is need to improve internal processes due to the low, negative or stagnation of technical efficiency change so as to improve the research productivity of African public universities.

\section{Conclusions}

The total factor productivity growth for African public universities was majorly attributed to research productivity $(6.8 \%)$ rather than teaching productivity $(0.7 \%)$. The teaching and research total factor productivity growth of African public universities is majorly attributed to technological advancements in both the teaching and research functions rather than to the optimization of teaching and research resources by university managers. The implication is that whereas African public universities are embracing modern and innovative teaching \& research methods, there is need, however, to improve the internal processes efficiency. Theoretically, all the universities in study sample would have saved up to $7.5 \%$ of their inputs to produce the same quantities of teaching and research outputs. There were, however, considerable differences in productivity growth between African public universities. South African based universities were relatively more productive in their teaching and research functions than their non-South African based counterparts. South African based universities hence produced more graduates, more doctorates and peer reviewed publications than their non-South African based universities.

The study had a number of limitations to be addressed by future researchers. Annual graduation numbers captured each academic year did not reflect repetition rates and quality of degrees awarded. Country and regional specifics were not considered because only one Flagship University was considered for countries outside the Republic of South Africa and hence it was not possible to satisfy the DEA sample size requirements. Classification of the universities input and output variables into the three broad discipline clusters: Humanities, Business \& Management and Science, Engineering \& Technology could be further explored to ascertain the productivity of African public universities in three disciplines. Distinction among disciplines would also capture potential differences in resource intensity by fields of study. Regional and county specific productivity analysis could further be explored by future researchers. 


\section{References}

Agasisti, T., \& Perez-Esparcells, C. (2009). Comparing efficiency in a cross-country perspective: The case of Italian and Spanish state universities. Higher Education, 59(1): 85-103.

Bailey, T., Cloete, N., \& Pilley, P. (2012). Universities and Economic Development in Africa; Case Study: Uganda and Makerere University.

Boshof, N. (2010). Cross-national higher education performance indicators: ISI publication output figures for 16 selected African universities. Paper prepared for the Higher Education Research and Advocacy Network in Africa (HERANA).

Carrington, R., Coelli, T., \& Rao, D.S.P. (2005). The Performance of Australian Universities:Conceptual issue and preliminary results. Economic Papers, 24 (2):145-63.

Castano, M.C.N., \& Cabanda, E.(2007). Sources of Efficiency and Productivity growth in the Philippines State Universities and Colleges; A non-parametric approach. International Business \& Economics Research Journal, 6(6):79-90.

Caves, D.W., Chistensen, L.R., \& Diewert, W.E. (1982). The economic theory of index numbers and the measurement of inputs, outputs and productivity. Econometrica, 50 (6):1393-1414.

Charnes, A., Cooper, W.W., \& Li, S.L. (1989). Using data envelopment analysis to evaluate efficiency in the economic-performance of Chinese Cities. Socio-Economic Plan Sciences 23(6):325-344.

Charnes, A., Cooper, W.W., \& Rhodes, E.L. (1978).Measuring the efficiency of decision making units. European Journal of Operational Research, 2(6):429-444.

CHET (2013). Higher level knowledge production: CHET data profiles of four universities.

Coelli, T.J., Rao, D.S.P., O’Donell, C.J., \& Battesse, G.E.(2005). An introduction to efficiency and productivity analysis, Springer, Second Edition.

Common Wealth of Australian. (1997). Data envelopment analysis: A technique for measuring the efficiency of government service delivery.Centrum Cathedra, 4(2):197-215.

Cooper, W.W., Ramon,N., Ruiz,J.L.,\&Sirvent,I.(2007). Choosing weights from alternative optimal solutions of dual multiplier models in DEA. European Journal of Operation Research, 180(10): 443-458.

Cooper, W.W., Seiford, L. M., \& Tone, K. (2000). Data Envelopment Analysis. Boston: Kluwer Academic Publishers.

Cunha, M., \& Rocha, V. (2012). On the efficiency of public higher education institutions in Portugal: An exploratory study. FEP Working Papers, 468, September.

Fare, R., Grosskopf, S., \& Lovell, C.A. (1994). Production frontiers. Cambridge University Press

Fare, R., Grosskopf, S., Bjorn, L., \& Pontus, R. (1992). Productivity changes in Swedish Pharmacies, 19801989. A Non-parametric Malmquist Approach. Journal of Productivity Analysis. 3(1/2): 85-101.

Garcia-Aracil, A., \& Navarro-Milla, I. (2006). Efficiency and Total factor productivity growth in Spanish Public Universities, 1994-2002.

Garcia-Aracil, A., \& Lopez-Inesta, E.(2007). An analysis of the Spanish Public Universities Missions in efficiency terms, 1995/96-2005/06

Grosskopf, S. (2002). Some remarks on productivity and its decomposition.

Johnstone, D.B. (2006). Financing higher education: Cost-sharing in international perspective. Center for Higher Education, Lynch, School of Education, Boston College, Chestnut Hill, Massachusetts.

Kantabutra, S., \& Tang., J.C.S. (2010). Efficiency analysis of public universities in Thailand.Tertiary Education and Management, 16(1):15-33.

Kuah, C.T., \& Wong, K.Y. (2011). Efficiency assessment of universities through data envelopment analysis. Procedia Computer Science, 3: 499-506.

Kosor, R.M. (2013). Efficiency measurement in higher education: concepts, methods and perspective. ProcediaSocial and Behavioral Sciences, 106:1031-1038.

Lehmann, E., \& Warning, S. (2002). Teaching or research?. What affects the efficiency of universities?. University of Konstanz. Working Paper No.322.

Malmquist, S. (1953). Index numbers and indifference curves. Trobayos ed Estatistica, 4(1): 209-242.

Mawson, P., Carlaw, K.I., \& Mclellan, N. (2003). Productivity measurement: Alternative approaches and estimates. New Zealand Treasuring Working paper 03/12.

Mutala, S.M. (2009). Challenges of doing research in Sub-Saharan African Universities:Digital scholarship opportunities. Journal of Humanities and Social Sciences, 1(1):1-10

Ng, Y.C., \& Li, S. (2006). Efficiency and Productivity growth in Chinese Universities, 1998-2002. A paper presented at the Asia-Pacific productivity Conference (APPC), Soeul National University, Seoul, Korea, 17-19 August.

Nishimuzu, M., \& Page, J.M. (1982). Total factor productivity growth, technological progress and technical efficiency change: Dimensions of productivity change in Yugoslavia 1965-78. Economic Journal, 92:920936. 
Norman, M., \& Stocker, B. (1991). Data Envelopment Analysis: the assessment of performance. New York, USA, Wiley.

Obong, Q.O. (2004). Academic dilemmas under neo-liberal education reforms: A review of Makerere University, Uganda. In Africa Universities in the twenty-first century, edited by Zeleza, P.T., \& Olukoshi, A., 108-125, Council for the Development of Social Science Research in Africa, Lightning Source UK Ltd.

Pastor, J.T., Ruiz, J.L., \& Servent, I. (2001). A statistical test for nested radial DEA models. Operations Research, 50(4): 728-735

Ramanathan, R. (2003). An introduction to data envelopment analysis:A tool for performance measurement. Sage Publications Ltd 6 Benhill Street. London EC2A4PU.

Sav, G.T. (2012). Productivity, efficiency and managerial performance regress and gains in United States universities: A data envelopment analysis. Advances in Management and Applied Economics, 2(3):13- 32.

Sawyerr, A. (2004). Challenges facing African Universities: Selected Issues. African Studies Review, 47(1):1-59. Smith, P.C., \& Street, A. (2006). Analysis of secondary school efficiency. Research Report 788.

Wolszczak-Derlack, J., \& Parteka, A. (2011). Efficiency of European public higher education institutions: A two-stage multi country approach. Scientometrics, 89(3):887-917.

Worthington, A.C., \& Lee, B. (2008). Efficiency and total factor productivity growth in Australian Universities, 1998-2003. Economics of Education Review, 27 (2008): 285-298. 